\title{
INOVASI KURIKULUM: STUDI KASUS DI MADRASAH ALIYAH AL-ISLAM JORESAN MLARAK PONOROGO
}

\author{
Abdah Munfaridatus Sholihah \\ Institut Agama Islam Sunan Giri (INSURI) Ponorogo \\ abdahmunfarida.20@gmail.com
}

\begin{abstract}
:
The curriculum is one component that is crucial in an education system, because the curriculum is a tool to achieve educational goals and at the same time as a guide in the implementation of teaching at all types and levels of education. Thus the curriculum is always dynamic in order to better adapt to various developments that occur. Every educator must understand the development of the curriculum, because it is the most important pedagogical formulation in the educational context, and the curriculum will illustrate how the work done helps students develop their potential in the form of physical, intellectual, emotional, and social, religious.

To uncover the curriculum innovations carried out at MA Al-Islam Joresan Mlarak Ponorogo, the author will examine how the curriculum innovations implemented at MA Al-Islam Joresan before and after the implementation of the full day school program and how the impact of curriculum innovation on educational outcomes and student self-development at MA Al-Islam Joresan? And researchers apply the type of qualitative research methods, and data collection techniques include in-depth interviews, observation and documentation. Then the data analysis technique used in this study uses the concept given by Miles \& Huberman. From the results of the study it was found that the curriculum innovation at Joresan Aliyah Al-Islam Madrasah was carried out in two stages, the first was curriculum innovation before the implementation of the full day school classroom program. The first phase was implemented in 1984, while the second innovation was carried out in 2010 by implementing a full day class program. The impact of curriculum innovation in Madrasah Aliyah Al-Islam Joresan is very influential on student learning outcomes and self-development of full day class students.
\end{abstract}

Keywords: Educational Innovation, Curriculum, Curriculum Development.

\section{PENDAHULUAN}

Kurikulum merupakan salah satu komponen yang sangat menentukan dalam suatu sistem pendidikan, karena itu kurikulum merupakan suatu alat untuk mencapai tujuan pendidikan dan sekaligus sebagai pedoman dalam pelaksanaan pengajaran pada semua jenis dan tingkat pendidikan. Dengan demikian kurikulum senantiasa bersifat dinamis guna lebih menyesuaikan dengan berbagai perkembangan yang terjadi. Setiap pendidik harus memahami perkembangan kurikulum, karena merupakan formulasi pedagogis yang paling penting dalam konteks pendidikan, dan kurikulum akan tergambar bagaimana usaha yang dilakukan membantu siswa dalam mengembangkan potensinya berupa fisik, intelektual, emosional dan sosial, keagamaan dan sebagainya. ${ }^{1}$

\footnotetext{
${ }^{1}$ Ramayulis, Ilmu Pendidikan Islam, ( Jakarta : Kalam Mulia, 2006), hlm. 149.
} 
Sekolah mendapat pengaruh dari kekuatan-kekuatan yang ada dalam masyarakat, terutama Pendidikan Tinggi, masyarakat dan sistem nilai. ${ }^{2}$ Ketiga faktor itulah yang mempengaruhi pengembangan kurikulum yang ada di sekolah. Madrasah Aliyah Al-Islam Joresan merupakan salah satu lembaga pendidikan yang tercover dalam pondok pesantren yang ada di daerah Ponorogo selatan, yang terus menerus mengadakan inovasi dalam kurikulumnya, mulai dari tahun berdirinya hingga sampai sekarang.

Berdasarkan hasil wawancara dengan Bapak Syafruddin Rusydi pada tanggal 28 Desember 2012, beliau merupakan waka kurikulum di Madrasah Aliyah Al-Islam. Inovasi kurikulum di Madrsasah Aliyah Al-Islam ini sudah dimulai sejak tahun 1984, yakni dilaksanakannya kurikulum program kelas eksperimen/intensif untuk siswa yang ingin masuk ke jenjang Madrasah Aliyah Al-Islam Joresan yang berasal dari SMP/MTs di luar Al-Islam Joresan. Program kelas eksperimen/intensif ini sudah berjalan selama \pm 26 tahun. Beliau juga menjelaskan bahwa mulai tahun ajaran 2010 di Madrasah Aliyah Al-Islam telah diberlakukan kurikulum baru yakni program kelas full day school, program ini menggantikan program kelas eksperimen/intensif yang dulunya pernah diterapkan selama \pm 26 tahun.

Penerapan kurikulum baru program kelas full day school ini adalah suatu bentuk inovasi pendidikan yang dilaksanakan di Madrasah Aliyah Al-Islam Joresan, program kelas full day ini menawarkan pembelajaran dengan waktu tempuh selama 3 tahun saja, program ini lebih singkat dibandingkan dengan program sebelumnya yaitu program kelas eksperimen/intensif yang memerlukan waktu tempuh belajar siswa selama 4 tahun. Penerapan program full day school ini sudah tentu menciptakan beberapa inovasi lainnya dalam bidang kurikulum seperti struktur mata pelajaran, media, materi, metode dan sistem penilaian yang digunakan dalam program tersebut.

Inovasi kelas full day bagi siswa kelas X yang ingin belajar di Madrasah Aliyah AlIslam Joresan ini diharapkan mampu menjadi lulusan yang berkompeten baik dalam pendidikan agama Islam dan pendidikan umum yang nantinya akan dipelajarinya di Madrasah Aliyah Al-Islam Joresan tersebut, jika hasil dari inovasi pendidikan yang dilakukan ini akan membawa dampak yang positif baik dari hasil pendidikan maupun baik bagi penerima inovasi pendidikan itu sendiri yang tidak lain adalah siswa Madrasah Aliyah Al-Islam, maka akan dijadikan suatu bentuk inovasi yang benar-benar akan mewujudkan visi, misi dan tujuan dari pondok pesantren Al-Islam secara khusus dan tujuan pendidikan secara umum. Inovasi hlm. 105 .

${ }^{2}$ Oemar Hamalik, Manajemen Pengembangan Kurikulum, (Bandung : PT Remaja Rosdakarya, 2008), 
kurikulum pendidikan yang dilaksanakan pada saat ini sudah pasti berpengaruh terhadap beberapa program kurikulum pendidikan di Madrasah Aliyah Al-Islam terutama pada struktur mata pelajaran dan alokasi waktu pembelajaran yang dilaksanakan, dan membawa berbagai inovasi lainnya baik pada media pembelajaran, metode pembelajaran, dan sistem penilaian yang digunakan di Madrasah Aliyah Al-Islam Joresan.

\section{METODE PENELITIAN}

\section{Pendekatan dan Jenis Penelitian}

Dalam penelitian ini digunakan metodologi penelitian pendekatan kualitatif. Dan jenis penelitian yang digunakan adalah studi kasus, yaitu merupakan penelitian yang dilakukan terhadap suatu "kesatuan sistem". Kasatuan ini dapat berupa program, kegiatan, peristiwa, atau sekelompok individu yang terikat oleh tempat, waktu dan ikatan tertentu. Dan studi kasus adalah suatu penelitian yang diarahkan untuk menghimpun data, mengambil makna, memperoleh pemahaman dari kasus tersebut. ${ }^{3}$

\section{Instrumen Penelitian}

Ciri khas penelitian kualitatif tidak dapat dipisahkan dari pengamatan berperanserta, sebab peranan penelitilah yang menentukan keseluruhan skenarionya. ${ }^{4}$ Untuk itu, dalam penelitian ini, peneliti bertindak sebagai instrument kunci, partisipan penuh sekaligus pengumpul data sedangkan instrument yang lain sebagai penunjang.

\section{Sumber dan Tekhnik Pengumpulan Data}

Sumber dan data utama dalam penelitian kualitatif adalah kata-kata dan tindakan, selebihnya adalah tambahan seperti dokumen dan lainnya. Oleh karena itu, tekhnik pengumpulan data yang digunakan dalam penelitian ini adalah observasi berperan serta (participan observation), wawancara mendalam (in depth interview) dan dokumentasi (document review). ${ }^{5}$ Tekhnik tersebut digunakan peneliti, karena fenomena akan dapat dimengerti maknanya secara baik, apabila peneliti melakukan interaksi dengan subyek penelitian dimana fenomena tersebut berlangsung.

\section{a. Tekhnik Wawancara}

${ }^{3}$ Ibid, hlm. 64.

${ }^{4}$ Pengamatan berperanserta adalah sebagai penelitian yang bercirikan interaksi sosial yang memakan waktu cukup lama antara peneliti dan subyek dalam lingkungan subyek, dan selama itu data dalam bentuk catatan lapangan dikupulkan secara sistematis dan catatan tersebut berlaku tanpa gangguan. Lihat dalam Lexy Moleong, Metodologi Penelitian Kualitatif, h. 117.

5 Sugiyono, Metode Penelitian Pendidikan : Pendekatan Kuantitatif, Kualitatif dan RD (Bandung : Alfabeta, 2005)h. 309. 
Tekhnik wawancara yang digunakan dalam penelitian ini adalah wawancara mendalam, artinya peneliti mengajukan beberapa pertanyaan secara mendalam berhubungan dengan fokus permasalahan, sehingga dengan wawancara mendalam ini data-data bisa terkumpulkan semaksimal mungkin. Disamping itu juga menggunakan wawancara terbuka melalui FGD (Focus Group Discussion), yaitu proses pengumpulan data mengenai suatu permasalahan tertentu yang sangat spesifik melalui diskusi kelompok. Pihak yang dijadikan informan dalam penelitian ini adalah sebagai berikut:

1) Kepala Sekolah Madrasah Aliyah Al-Islam Joresan Mlarak Ponorogo.

2) Waka kurikulum Madrasah Aliyah Al-Islam Joresan Mlarak Ponorogo.

3) Bagian Kesiswaan Madrasah Aliyah Al-Islam Joresan Mlarak Ponorogo.

4) Wali kelas dan siswa kelas full day di Madrasah Aliyah Al-Islam Joresan Mlarak Ponorogo.

\section{b. Tekhnik Observasi}

Observasi diartikan sebagai pengamatan dan pencatatan secara sistematik terhadap gejala yang tampak pada objek penelitian. ${ }^{6}$ Hasil observasi dalam penelitian ini dicatat dalam catatan lapangan (cl). Sebab catatan lapangan merupakan alat yang sangat penting dalam penelitian kualitatif. Dalam penelitian kualitatif peneliti mengandalkan pengamatan dan wawancara dalam pengumpulam data di lapangan. Format rekaman hasil observasi catatan lapangan dalam penelitian ini menggunakan format hasil rekaman observasi.

\section{c. Tekhnik Dokumentasi}

Dokumen merupakan catatan peristiwa yang sudah berlalu, dokumen bisa berbentuk tulisan, gambar, atau karya-karya monumental dari seseorang. Dokumen yang berbentuk tulisan misalnya catatan harian, sejarah kehidupan (life histories), ceritera, biografi, peraturan, kebijakan. Dokumen yang berbentuk gambar, misalnya foto, gambar hidup, sketsa dan lain-lain. Dokumen yang berbentuk karya misalnya karya seni yang yang dapat berupa gambar, patung film, dan lain-lain. Studi dokumen merupakan pelengkap dari penggunaan metode observasi dan wawancara dalam penelitian kualitatif. $^{7}$

\section{Analisis data}

\footnotetext{
${ }^{6}$ Margono, Metodologi Penelitian Pendidikan, (Jakarta : Rineka Cipta, 2009), hlm. 158-159.

${ }^{7}$ Sugiyono, Memahami Penelitian Kualitatif, hlm. 82.
} 
Teknik analisa data yang digunakan dalam penelitian ini menggunakan konsep yang diberikan Miles \& Huberman yang mengemukakan bahwa aktivitas dalam analisis data kualitatif dilakukan secara interaktif dan berlangsung secara terus-menerus pada setiap tahapan penelitian sehingga sampai tuntas, dan datanya sampai jenuh. Aktifitas dalam analisis data, meliputi data reduction, data display dan conclusion. ${ }^{8}$

\section{Pengecekan Keabsahan data}

Keabsahan data merupakan konsep penting yang diperbaharui dari konsep kesatuan (validitas) dan keandalan (realibilitas). ${ }^{9}$ Derajat kepercayaan data (kredibilitas data) dapat dilakukan dengan :

a. Perpanjangan Keikutsertaan. Peneliti dalam penelitian kualitatif adalah instrument itu sendiri. Keikutsertaan peneliti sangat menentukan dalam pengumpulan data. Dalam hal ini keikutsertaan tersebut tidak hanya dilakukan dalam waktu singkat, tetapi memerlukan perpanjangan keikutsertaan peneliti pada latar penelitian. Maka perpanjangan keikutsertaan peneliti dalam penelitian ini akan memungkinkan peningkatan derajat kepercayaan data yang dikumpulkan.

b. Pengamatan Yang Tekun. Ketekunan pengamatan yang dimaksud dalam penelitian ini adalah menemukan ciri-ciri dan unsur-unsur dalam situasi yang sangat relevan dengan persoalan atau isu yang sedang dicari. Jadi, apabila perpanjangan keikutsertaan menyediakan lingkup, maka ketekunan pengamatan menyediakan kedalaman.

c. Triangulasi. Triangulasi dalam pengujian kredibilitas ini diartikan sebagai pengecekan data dari berbagai sumber dengan berbagai cara, dan berbagai waktu. Dengan demikian terdapat triangulasi sumber, triangulasi teknik pengumpulan data, dan waktu. Dan triangulasi juga dapat dilakukan dengan cara mengecek hasil penelitian, dari tim peneliti lain yang diberi tugas melakukan pengumpulan data. ${ }^{10}$

d. Pengecekan Sejawat Melalui Diskusi. Teknik ini dilakukan peneliti dengan cara mengekspos hasil sementara atau hasil akhir yang diperoleh dalam bentuk diskusi analistik dengan rekan-rekan sejawat. Hal ini dilakukan dengan maksud : (a) untuk membuat agar peneliti tetap mempertahankan sikap terbuka dan kejujuran, (b) diskusi dengan sejawat ini memberikan suatu kesempatan awal yang baik untuk mulai menjajaki dan menguji hipotesis yang muncul dari pemikiran peneliti.

20.

${ }^{8}$ Matthew B. Miles, A. Michael Huberman, Analisa Data Kualitatif, (Jakarta : UI-Press, 1992), hlm.

\footnotetext{
${ }^{9}$ Lexy Moleong, Metodologi Penelitian Kualitatif...., hlm. 175.

${ }^{10}$ Sugiyono, Memahami Penelitian Kualitatif, hlm. 125-128.
} 


\section{HASIL}

\section{Inovasi Kurikulum di Madrasah Aliyah Al-Islam Joresan}

\section{a. Sebelum diterapkannya Proram Full Day School Tingkat Madrasah Aliyah}

Berdasarkan hasil wawancara dengan Ahmat Budairi pada tanggal 23 Januari 2013, beliau mengatakan bahwa sebelum diterapkannya program full day school bagi siswa kelas X yang menimba ilmu di Madrasah Aliyah Al-Islam, yang mana siswa kelas X tersebut merupakan siswa baru yang berasal dari SMP/MTs di luar Al-Islam, siswa baru tersebut diwajibkan untuk mengikuti program kelas tambahan 1 tahun. Dengan demikian siswa baru dari lulusan SMP/MTs menempuh pendidikan 4 tahun untuk menyelesaikan sekolahnya. Dalam program kelas intensif ini siswa diberikan mata pelajaran mulai kelas satu sampai kelas tiga tingkat Tsanawiyah, Kemudian mereka akan naik ke kelas $\mathrm{X}$ Intensif, mereka akan mulai bergabung dengan siswa Madrasah Aliyah Al-Islam umum lainnya ketika mereka memasuki kelas XI dan XII. Sehingga tidak heran jika waktu pembelajaran yang dibutuhkan mencapai empat tahun, untuk mengejar materi pelajaran ketika mereka akan memasuki kelas XI dan kelas XII.

Perhatian masyarakat mengenai program intensif ini sangat bagus sekali, terbukti dengan diadakannya program tersebut banyak siswa yang masuk dan menuntut ilmu di Madrasah Aliyah Al-Islam, siswa yang belajar disana tidak hanya berasal dari daerah lokal saja melainkan juga berasal dari luar daerah seperti : Sumatera, Kalimantan, Sulawesi, Jawa Barat, Jawa Tengah dan lain sebagainya. Program intensif ini mulai diterapakan \pm pada tahun 1984, dan program ini berjalan kurang lebih selama 26 tahun.

\section{b. Setelah diterapkannya Program Full Day School Tingkat Madrasah Aliyah}

Berdasarkan wawancara dengan Syafruddin Rusydi, beliau mengatakan program full day school ini merupakan inovasi kurikulum kedua setelah adanya program eksperimen atau intensif, inovasi kedua ini berupa program full day school yang nantinya diharapkan dapat sukses dan sesuai dengan harapan dan kebutuhan dari masyarakat. Setelah program kelas eksperimen/intensif berjalan kurang lebih selama 26 tahun, ada beberapa wali siswa yang mengajukan beberapa konspirasinya kepada pihak Madrasah Aliyah Al-Islam untuk menerapkan program kurikulum baru mengenai waktu tempuh pembelajaran yang dilaksanakan di Madrasah Aliyah Al-Islam Joresan.

Beliau juga menambahkan bahwa banyak pihak baik dari orang tua dan siswa menginginkan waktu pembelajaran yang ditempuh pada waktu memasuki Madrasah Aliyah Al-Islam ini dilaksanakan selama tiga tahun, dengan demikian mereka bisa 
menghemat waktu dan biaya sekolah. Rencana ini mereka ungkapkan pada pihak lembaga Madrasah Aliyah Al-Islam, sudah pasti untuk pelaksanaannya memerlukan program-program baru serta inovasi baru dalam pendidikan dan pembelajaran. Sebagai lembaga yang melayani masyarakat sesuai dengan kebutuhan mereka, maka pada tahun 2010 pihak Madrasah Aliyah Al-Islam Joresan ini mengadakan suatu inovasi pendidikan dengan diterapkannya kurikulum pembelajaran baru bagi siswa yang ingin menuntut ilmu di Madrasah Aliyah Al-Islam, tidak hanya mengubah waktu pembelajaran akan tertapi struktur mata pelajaran pun juga pasti berubah karena waktu tempuh yang awalnya empat tahun disingkat menjadi tiga tahun. Program ini dinamakan full day school untuk kelas X dan XI bagi siswa baru yang masuk ke Madrasah Aliyah Al-Islam selain lulusan dari Madrasah Tsanawiyah Al-Islam Joresan. Implementasi full day school di Madrasah Aliyah Al-Islam ini dilaksanakan dengan alokasi waktu pelajaran lebih banyak dibandingkan kelas yang lainnya. Yakni pelajaran dilaksanakan mulai pukul 07.00 WIB sampai pukul 15.30 WIB.

\section{Dampak dari Implementasi Inovasi Kurikulum di Madrasah Aliyah Al-Islam Joresan}

Setelah dilaksanakannya program full day school tersebut kurang lebih selama tiga tahun, sudah pasti memiliki dampak atau implikasi dari pelaksanaan program full day tersebut terhadap siswa. Berdasarkan wawancara dengan Ahmat Budairi, beliau mengungkapkan bahwasannya dampak dari implementasi program baru dalam kurikulum di Madarsah Aliyah Al-Islam Joresan ini adalah sangat banyak sekali. Menurut beliau, setelah dilaksanakannya program full day school ini, banyak siswa yang mengeluh tidak kuat dengan padatnya aktivitas pembelajaran yang dijadwalkan, karena mereka dituntut menempuh 60 Jam pelajaran dalam satu minggunya.

Alif Mustafida adalah seorang siswa kelas full day yang sekarang duduk di kelas XI IPS, dia mengaku sangat kelelahan dengan adanya 60 jam pelajaran dalam seminggu. Mereka harus belajar ekstra time dalam setiap mata pelajaran yang sebelumnya mereka belum pernah mempelajarinya, seperti mata pelajaran nahwu dan shorof. Berbeda dengan Alif, Abdullah Ma'ruf mengaku juga sangat keberatan dengan waktu pembelajaran yang sangat padat, mereka masuk kelas mulai pukul 07.00 WIB dan pulang pukul 15.30 WIB, dia kadang tidak bisa konsentrasi maksimal ketika jam pelajaran memasuki pukul 14.00 WIB, dia sering mengantuk ketika diberi pelajaran. Apalagi rumahnya terbilang agak jauh, sehingga terkadang magrib dia baru sampai rumah. Dan aktifitas seperti itu harus dia jalani setiap harinya, dan itu snagat melelahkan baginya. Afif Zakki seorang siswa kelas XII IPS 
mengaku juga sangat kecewa dengan program full day ini karena dia tidak bisa mengikuti organisasi kesiswaan seperti OPMI dan andalan koordinator seperti teman-teman yang lainnya, karena dia ingin sekali mencari pengalaman dan mengembangkan bakatnya dibidang kesenian.

Memang peran keberadaan organisasi kesiswaan yang ada di Madrasah Aliyah AlIslam sangat berpengaruh terhadap pengembangan diri dan life skill siswa, melalui organisasi tersebut siswa dapat banyak mengambil pengalaman dan melatih mental mereka ketika mereka harus mengurusi adik-adik kelas mereka. Dengan terbiasa tampil di depan publik, mereka mendapatkan pengalaman mental dan ini dapat bermanfaat sekali ketika mereka nanti menghadapi amaliyatul tadris, yaitu kegiatan yang wajib diikuti seluruh siswa baik dari kelas full day ataupun kelas umum lainnya.

Setelah program full day school sudah berjalan selama tiga tahun dan pihak lembaga sudah mengetahui bagaimana dampaknya terhadap hasil belajar serta perkembangan peserta didiknya, dengan demikian maka Ahmat Budairi mengatakan bahwa setelah mengadakan evaluasi dari tahun pertama sampai tahun ketiga dari pelaksanaan program full day tersebut maka pihak lembaga Madrasah Aliyah Aliyah Al-Islam Joresan merencakan akan menggunakan kembali program kelas eksperimen/intensif seperti tahun-tahun sebelumnya, pertimbangan ini sesuai dengan keluhan siswa.

\section{PEMBAHASAN}

\section{Bagan Inovasi Kurikulum di Madrasah Aliyah Al-Isam Joresan Mlarak Ponorogo}

a. Kurikulum M.A Al-Islam Joresan Pra Full Day School

Tujuan : Mewujudkan lulusan yang berwawasan luas baik dalam bidang umum maupun agama serta berprestasi sesuai minat dan bakat dengan berlandaskan Iman dan Taqwa.

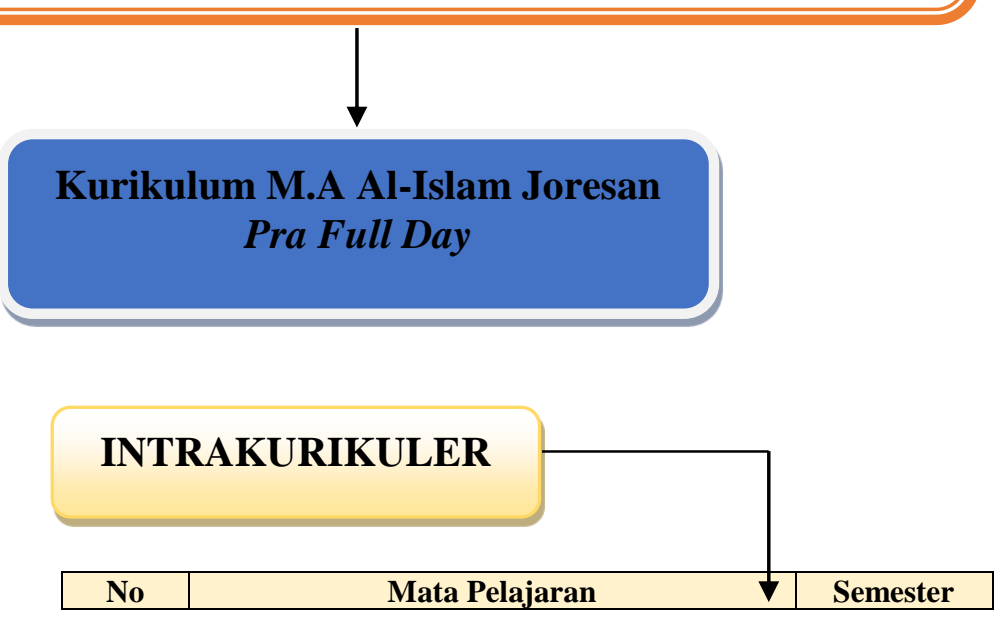




\begin{tabular}{|c|c|c|c|}
\hline & & $\mathbf{I}$ & II \\
\hline \multirow[t]{12}{*}{ A. } & Pendidikan Agama Islam & & \\
\hline & 1. Al-Qur'an dan hadits & & \\
\hline & 1.1 Al-Qur'an & $1 \mathrm{JP}$ & $1 \mathrm{JP}$ \\
\hline & 1.2 Al-Tajwid & $1 \mathrm{JP}$ & $1 \mathrm{JP}$ \\
\hline & 1.3 Al-Hadits & $3 \mathrm{JP}$ & $3 \mathrm{JP}$ \\
\hline & $1.4 \mathrm{Al}-\mathrm{Tafsir}$ & $2 \mathrm{JP}$ & $2 \mathrm{JP}$ \\
\hline & 2. Aqidah dan Akhlak & & \\
\hline & 2.1 Aqoid & $3 \mathrm{JP}$ & $3 \mathrm{JP}$ \\
\hline & 2.2 Ta'lim Muta'allim & - & $1 \mathrm{JP}$ \\
\hline & 3. Fiqih & $5 \mathrm{JP}$ & $5 \mathrm{JP}$ \\
\hline & 4. SKI & & \\
\hline & 4.1 Tarikh Islam & $2 \mathrm{JP}$ & $2 \mathrm{JP}$ \\
\hline \multirow[t]{13}{*}{$\mathrm{B}$} & Bahasa & & \\
\hline & 1. Bahasa dan Sastra Indonesia & $2 \mathrm{JP}$ & $2 \mathrm{JP}$ \\
\hline & 2. Bahasa dan Sastra Arab & & \\
\hline & 2.1 Bahasa Arab & $\begin{array}{l}12 \\
\mathrm{JP}\end{array}$ & \\
\hline & 2.2 Al-Imla' & $1 \mathrm{JP}$ & $1 \mathrm{JP}$ \\
\hline & 2.3 Al-Muthala'ah & - & $3 \mathrm{JP}$ \\
\hline & 2.4 Al-Mahfudlot & $2 \mathrm{JP}$ & $2 \mathrm{JP}$ \\
\hline & 2.5 Khot & $1 \mathrm{JP}$ & $1 \mathrm{JP}$ \\
\hline & 2.6 Nahwu & - & $3 \mathrm{JP}$ \\
\hline & 2.7 Sharaf & - & $2 \mathrm{JP}$ \\
\hline & 2.8 Balaghah & - & $1 \mathrm{JP}$ \\
\hline & 2.9 Insya' & - & $2 \mathrm{JP}$ \\
\hline & 3. Bahasa Inggris & $3 \mathrm{JP}$ & $3 \mathrm{JP}$ \\
\hline $\mathrm{D}$ & Matematika & $1 \mathrm{JP}$ & $1 \mathrm{JP}$ \\
\hline \multirow[t]{5}{*}{$\mathrm{E}$} & Ilmu Pengetahuan Sosial & & \\
\hline & 1. Sejarah & - & \\
\hline & 2. Geografi & $1 \mathrm{JP}$ & $1 \mathrm{JP}$ \\
\hline & 3. Ekonomi & $1 \mathrm{JP}$ & $1 \mathrm{JP}$ \\
\hline & 4. Sosiologi & - & \\
\hline \multirow[t]{4}{*}{$\mathrm{F}$} & Ilmu Pengetahuan Alam & & \\
\hline & 1. Fisika & $1 \mathrm{JP}$ & $1 \mathrm{JP}$ \\
\hline & 2. Kimia & $1 \mathrm{JP}$ & $1 \mathrm{JP}$ \\
\hline & 3. Biologi & $1 \mathrm{JP}$ & $1 \mathrm{JP}$ \\
\hline $\mathrm{G}$ & Pendidikan Jasmani & $2 \mathrm{JP}$ & $2 \mathrm{JP}$ \\
\hline \multirow[t]{4}{*}{$\mathrm{H}$} & Muhadloroh & $2 \mathrm{JP}$ & $2 \mathrm{JP}$ \\
\hline & JUMLAH & & \\
\hline & MATA PELAJARAN & 21 & 26 \\
\hline & JAM PELAJARAN (1 MINGGU) & $\begin{array}{l}48 \\
\text { JP }\end{array}$ & $\begin{array}{l}48 \\
\text { JP }\end{array}$ \\
\hline
\end{tabular}

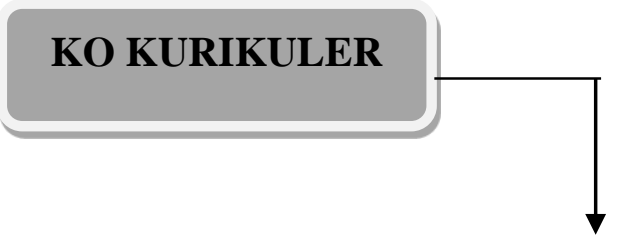




\begin{tabular}{|c|l|}
\hline No & \multicolumn{1}{c|}{ Kegiatan } \\
\hline 1. & Darsul Masa' \\
\hline 2. & Ibadah Amaliyah \\
\hline 3. & Hafalan surat-surat Juz 'Amma \\
\hline 4. & Hafalan Mata Pelajaran Muthola'ah \\
\hline 5. & Hafalan Mata Pelajaran Bahasa Arab \\
\hline 6. & Hafalan Mata Pelajaran Nahwu \\
\hline 7. & Hafalan Mata Pelajaran Shorof \\
\hline
\end{tabular}

\section{EKSTRAKURIKULER}

\begin{tabular}{|c|l|}
\hline No. & \multicolumn{1}{c|}{ Kegiatan } \\
\hline 1. & Kepramukaan \\
\hline 2. & Jami'iyyatul Qura' \\
\hline 3. & Drum band \\
\hline 4. & Band \\
\hline 5. & Koor \\
\hline 6. & PMR \\
\hline 7. & Volly \\
\hline 8. & Habsyi \\
\hline
\end{tabular}

\section{b. Kelebihan dan Kekurangan Kurikulum Pra Full Day School}

1) Kelebihan Kurikulum Pra Full Day School

a) Siswa lebih dapat maksimal dalam memahami pelajaran yang diberikan dengan alokasi waktu pembelajaran yang relatif maksimal (selama 4 tahun).

b) Siswa dapat memilih jurusan pendidikan yang dikehendakinya sesuai dengan kemampuan yang dimilikinya.

c) Siswa dapat mengikuti kegiatan organisasi kesiswaan sesuai dengan minat, bakat dan keterampilan yang dimilikinya.

d) Siswa berkesempatan bergabung dengan siswa kelas reguler lainnya ketika mereka memasuki kelas XI.

2) Kekurangan Kurikulum Pra Full day School

a) Waktu pembelajaran selama 4 tahun.

b) Meningkatnya biaya pendidikan karena waktu pembelajaran ditempuh selama 4 tahun.

c) Strategi pembelajaran yang digunakan masih tergolong konvensional diantaranya yaitu ceramah.

d) Media pembelajaran juga tergolong masih sederhana sekali, diantaranya yaitu hanya terpaku pada media papan tulis saja. 
e) Sumber belajar hanya terpaku juga pada buku-buku pelajaran pokok saja.

c. Kurikulum M.A Al-Islam Joresan Pasca Full day School

Tujuan :

1. Mewujudkan lulusan yang berwawasan luas dan berprestasi baik dalam bidang umum maupun agama dalam menyongsong era globalisasi dan era Tekhnologi berlandaskan Iman dan Taqwa.

2. Memberikan Nilai ekonomis dalam biaya pendidikan dengan adanya pendidikan 3 tahun seperti lembaga pendidikan pada umumnya.

\begin{tabular}{|c|c|c|c|}
\hline \multicolumn{2}{|c|}{$\begin{array}{c}\text { Kurikulum M.A Al-Islam Joresan } \\
\text { Pasca Full Day School }\end{array}$} & & \\
\hline \multicolumn{2}{|c|}{ INTRAKURIKULER } & & \\
\hline \multirow{2}{*}{$\begin{array}{l}\text { No } \\
\text { A }\end{array}$} & Mata Pelajaran & \multicolumn{2}{|c|}{ Semester } \\
\hline & Pendidikan Agama Islam & & \\
\hline & 1. Al-Qur'an dan hadits & & \\
\hline & 1.1 Al-Qur'an Hadits & $1 \mathrm{JP}$ & $1 \mathrm{JP}$ \\
\hline & 1.2 Al-Qur'an & $1 \mathrm{JP}$ & $1 \mathrm{JP}$ \\
\hline & 1.3 Al-Tajwid & $1 \mathrm{JP}$ & $1 \mathrm{JP}$ \\
\hline & 1.4 Al-Hadits & $1 \mathrm{JP}$ & $1 \mathrm{JP}$ \\
\hline & $1.5 \mathrm{Al}-\mathrm{Tafsir}$ & - & $1 \mathrm{JP}$ \\
\hline & 1.6 Mustholah Hadits & $1 \mathrm{JP}$ & $1 \mathrm{JP}$ \\
\hline & 2. Aqidah dan Akhlak & & \\
\hline & 2.1 Aqidah Akhlak & $1 \mathrm{JP}$ & $1 \mathrm{JP}$ \\
\hline & 2.2 Aqa'id & $2 \mathrm{JP}$ & $2 \mathrm{JP}$ \\
\hline & 3. Fiqih & & \\
\hline & 3.1 Fiqih & $4 \mathrm{JP}$ & $4 \mathrm{JP}$ \\
\hline & 3.2 Ushul Fiqih & - & $2 \mathrm{JP}$ \\
\hline & 3. Al-Fara'id & - & $1 \mathrm{JP}$ \\
\hline & 4. SKI & & \\
\hline & 4.1 SKI & $1 \mathrm{JP}$ & $1 \mathrm{JP}$ \\
\hline & 4.2 Tarikh Islam & $1 \mathrm{JP}$ & $1 \mathrm{JP}$ \\
\hline & 4.3 Al-Adyan & - & $1 \mathrm{JP}$ \\
\hline $\mathrm{B}$ & Pendidikan Kewarganegaraan & $1 \mathrm{JP}$ & $1 \mathrm{JP}$ \\
\hline $\mathrm{C}$ & Bahasa & & \\
\hline & 1. Bahasa dan Sastra Indonesia & $3 \mathrm{JP}$ & $2 \mathrm{JP}$ \\
\hline & 2. Bahasa dan Sastra Arab & & \\
\hline & 2.1 Bahasa Arab & $18 \mathrm{JP}$ & - \\
\hline & 2.2 Al-Imla' & $1 \mathrm{JP}$ & $1 \mathrm{JP}$ \\
\hline & 2.3 Al-Muthala'ah & - & $2 \mathrm{JP}$ \\
\hline & 2.4 Al-Mahfudlot & $2 \mathrm{JP}$ & $2 \mathrm{JP}$ \\
\hline & 2.5 Khot & $1 \mathrm{JP}$ & $1 \mathrm{JP}$ \\
\hline & 2.6 Nahwu & - & $4 \mathrm{JP}$ \\
\hline & 2.7 Sharaf & - & $2 \mathrm{JP}$ \\
\hline
\end{tabular}




\begin{tabular}{|c|c|c|c|}
\hline & 2.8 Balaghah & - & $1 \mathrm{JP}$ \\
\hline & 2.9 Insya' & - & $2 \mathrm{JP}$ \\
\hline & 3. Bahasa Inggris & $3 \mathrm{JP}$ & $3 \mathrm{JP}$ \\
\hline $\mathrm{D}$ & Matematika & $3 \mathrm{JP}$ & $3 \mathrm{JP}$ \\
\hline \multirow[t]{5}{*}{$\mathrm{E}$} & Ilmu Pengetahuan Sosial & & \\
\hline & 1. Sejarah & $1 \mathrm{JP}$ & $1 \mathrm{JP}$ \\
\hline & 2. Geografi & $1 \mathrm{JP}$ & $1 \mathrm{JP}$ \\
\hline & 3. Ekonomi & $1 \mathrm{JP}$ & $1 \mathrm{JP}$ \\
\hline & 4. Sosiologi & $1 \mathrm{JP}$ & $1 \mathrm{JP}$ \\
\hline \multirow[t]{4}{*}{$\mathrm{F}$} & Ilmu Pengetahuan Alam & & \\
\hline & 1. Fisika & $2 \mathrm{JP}$ & $2 \mathrm{JP}$ \\
\hline & 2. Kimia & $1 \mathrm{JP}$ & $1 \mathrm{JP}$ \\
\hline & 3. Biologi & $1 \mathrm{JP}$ & $1 \mathrm{JP}$ \\
\hline $\mathrm{G}$ & Pendidikan Jasmani & $2 \mathrm{JP}$ & $2 \mathrm{JP}$ \\
\hline $\mathrm{H}$ & $\begin{array}{lll}\text { Tekhnologi } & \text { Informasi } & \text { dan } \\
\text { Telekomunikasi } & & \\
\end{array}$ & $2 \mathrm{JP}$ & $2 \mathrm{JP}$ \\
\hline $\mathrm{I}$ & Muhadloroh & $2 \mathrm{JP}$ & $2 \mathrm{JP}$ \\
\hline $\mathrm{J}$ & Ilmu Jiwa & $1 \mathrm{JP}$ & $1 \mathrm{JP}$ \\
\hline \multirow[t]{4}{*}{ K } & Ta"lim Muta"allim & - & $1 \mathrm{JP}$ \\
\hline & JUMLAH & & \\
\hline & MATA PELAJARAN & 28 & 39 \\
\hline & JAM PELAJARAN (1 MINGGU) & $60 \mathrm{JP}$ & $60 \mathrm{JP}$ \\
\hline
\end{tabular}

\section{KO KURIKULER}

\begin{tabular}{|c|l|}
\hline No & \multicolumn{1}{|c|}{ Kegiatan } \\
\hline 1. & Ibadah Amaliyah \\
\hline 2. & Hafalan surat-surat Juz 'Amma \\
\hline 3. & Hafalan Mata Pelajaran Muthola'ah \\
\hline 4. & Hafalan Mata Pelajaran Bahasa Arab \\
\hline 5. & Hafalan Mata Pelajaran Nahwu \\
\hline 6. & Hafalan Mata Pelajaran Shorof \\
\hline 7. & Pembiasaan membaca Al-Qur'an sebelum pelajaran \\
\hline 8. & Pemberian tugas dengan media internet \\
\hline
\end{tabular}

\section{EKSTRAKURIKULER}




\begin{tabular}{|c|l|}
\hline No. & \multicolumn{1}{|c|}{ Kegiatan } \\
\hline 1. & Kepramukaan \\
\hline 2. & Jami'iyyatul Qura' \\
\hline 3. & Drum band \\
\hline 4. & Band \\
\hline 5. & Koor \\
\hline 6. & PMR \\
\hline 7. & Volly \\
\hline 8. & Habsyi \\
\hline 9. & Keputrian \\
\hline 10. & Futsal \\
\hline 11. & Theater \\
\hline 12. & Badminton \\
\hline 13. & Tari \\
\hline 14. & Kaligrafi \\
\hline 15. & Band \\
\hline 16. & Qasidah \\
\hline
\end{tabular}

\section{d. Kelebihan dan Kekurangan Kurikulum Pasca Full day School}

\section{1) Kelebihan Kurikulum Pasca Full day School}

a) Nilai ekonomis dalam hal biaya pendidikan karena ditempuh selama 3 tahun pelajaran saja.

b) Siswa dapat lulus dari M.A Al-Islam dengan waktu pembelajaran selama 3 tahun.

c) Strategi pembelajaran yang digunakan berpusat pada siswa dengan menggunakan strategi active learning, seperti group resume, reading a load, jigsaw learning, peer leason dan lain sebagainya.

d) Media pembelajaran yang digunakan adalah papan tulis, proyektor, laptop dan media yang disediakan oleh guru sendiri.

e) Sumber belajar siswa dapat diakses dengan buku-buku tambahan lainnya yang relevan dengan materi ajar yang diajarkan dan dapat pula diakses melalui media internet.

\section{2) Kekurangan Kurikulum Pasca Full Day School}

a) Siswa tidak dapat maksimal dalam memahami pelajaran yang diberikan dengan alokasi waktu pembelajaran yang relatif singkat (selama 3 tahun).

b) Siswa tidak dapat memilih jurusan pendidikan yang dikehendakinya.

c) Siswa tidak mengembangkan bakat dan minat yang dimilikinya karena tidak dapat mengikuti kegiatan organisasi kesiswaan yang ada karena padatnya jadwal pelajaran yang harus ditempuh siswa.

d) Siswa tidak dapat bergabung dengan siswa reguler lainnya. 
e) Siswa merasa kelelahan fisik karena padatnya waktu pembelajaran.

f) Guru kurang maksimal dalam memberikan materi pelajaran karena padatnya waktu pembelajaran.

e. Kurikulum M.A Al-Islam Modifikasi Antara Pra Full Day dan Pasca Full Day School

Tujuan :

Mewujudkan lulusan yang berwawasan luas dan berprestasi baik dalam bidang umum maupun agama dan mengembangkan minat dan bakat yang dimiliki sisiwa dalam menyongsong era globalisasi dan era Tekhnologi berlandaskan Iman dan Taqwa.
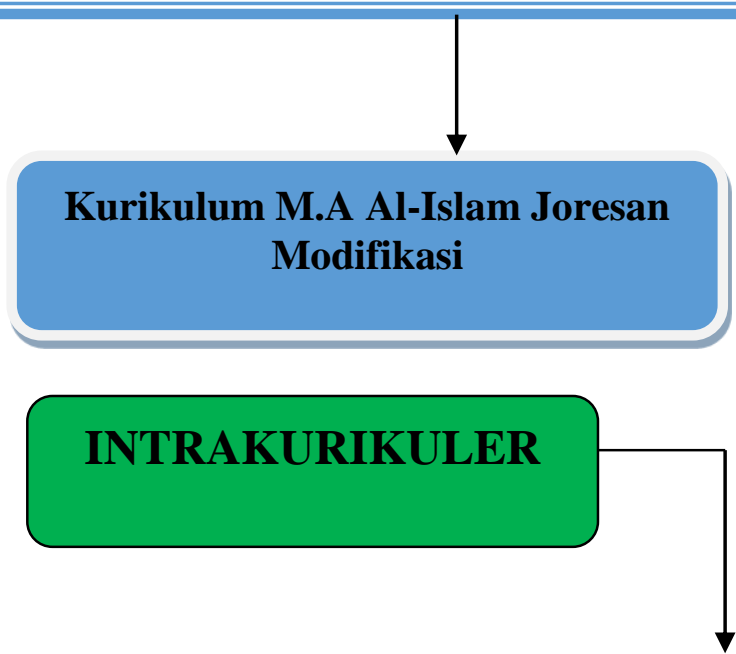

\begin{tabular}{|c|c|c|c|}
\hline \multirow{2}{*}{ No } & \multirow{2}{*}{ Mata Pelajaran } & \multicolumn{2}{|c|}{ Semester } \\
\hline & & I & II \\
\hline \multirow[t]{12}{*}{ A. } & Pendidikan Agama Islam & & \\
\hline & 1. Al-Qur'an dan hadits & & \\
\hline & 1.1 Al-Qur'an & $1 \mathrm{JP}$ & $1 \mathrm{JP}$ \\
\hline & 1.2 Al-Tajwid & $1 \mathrm{JP}$ & $1 \mathrm{JP}$ \\
\hline & 1.3 Al-Hadits & $3 \mathrm{JP}$ & $3 \mathrm{JP}$ \\
\hline & 1.4 Al-Tafsir & $2 \mathrm{JP}$ & $2 \mathrm{JP}$ \\
\hline & 2. Aqidah dan Akhlak & & \\
\hline & 2.1 Aqoid & $3 \mathrm{JP}$ & $3 \mathrm{JP}$ \\
\hline & 2.2 Ta'lim Muta'allim & - & $1 \mathrm{JP}$ \\
\hline & 3. Fiqih & $5 \mathrm{JP}$ & $5 \mathrm{JP}$ \\
\hline & 4. SKI & & \\
\hline & 4.1 Tarikh Islam & $2 \mathrm{JP}$ & $2 \mathrm{JP}$ \\
\hline \multirow[t]{10}{*}{ B } & Bahasa & & \\
\hline & 1. Bahasa dan Sastra Indonesia & 2 JP & $2 \mathrm{JP}$ \\
\hline & 2. Bahasa dan Sastra Arab & & \\
\hline & 2.1 Bahasa Arab & $\begin{array}{l}12 \\
\mathrm{JP}\end{array}$ & \\
\hline & 2.2 Al-Imla' & $1 \mathrm{JP}$ & $1 \mathrm{JP}$ \\
\hline & 2.3 Al-Muthala'ah & - & $3 \mathrm{JP}$ \\
\hline & 2.4 Al-Mahfudlot & $2 \mathrm{JP}$ & $2 \mathrm{JP}$ \\
\hline & 2.5 Khot & $1 \mathrm{JP}$ & $1 \mathrm{JP}$ \\
\hline & 2.6 Nahwu & - & $3 \mathrm{JP}$ \\
\hline & 2.7 Sharaf & - & $2 \mathrm{JP}$ \\
\hline
\end{tabular}




\begin{tabular}{|c|c|c|c|}
\hline & 2.8 Balaghah & - & $1 \mathrm{JP}$ \\
\hline & 2.9 Insya’ & - & $2 \mathrm{JP}$ \\
\hline & 3. Bahasa Inggris & $3 \mathrm{JP}$ & $3 \mathrm{JP}$ \\
\hline $\mathrm{D}$ & Matematika & $1 \mathrm{JP}$ & $1 \mathrm{JP}$ \\
\hline \multirow[t]{5}{*}{$\mathrm{E}$} & Ilmu Pengetahuan Sosial & & \\
\hline & 1. Sejarah & - & \\
\hline & 2. Geografi & $1 \mathrm{JP}$ & $1 \mathrm{JP}$ \\
\hline & 3. Ekonomi & $1 \mathrm{JP}$ & $1 \mathrm{JP}$ \\
\hline & 4. Sosiologi & - & \\
\hline \multirow[t]{4}{*}{$\mathrm{F}$} & Ilmu Pengetahuan Alam & & \\
\hline & 1. Fisika & $1 \mathrm{JP}$ & $1 \mathrm{JP}$ \\
\hline & 2. Kimia & $1 \mathrm{JP}$ & $1 \mathrm{JP}$ \\
\hline & 3. Biologi & $1 \mathrm{JP}$ & $1 \mathrm{JP}$ \\
\hline $\bar{G}$ & Pendidikan Jasmani & $2 \mathrm{JP}$ & $2 \mathrm{JP}$ \\
\hline \multirow[t]{4}{*}{$\mathrm{H}$} & Muhadloroh & $2 \mathrm{JP}$ & $2 \mathrm{JP}$ \\
\hline & JUMLAH & & \\
\hline & MATA PELAJARAN & 21 & 26 \\
\hline & JAM PELAJARAN (1 MINGGU) & $\begin{array}{l}48 \\
\text { JP }\end{array}$ & $\begin{array}{l}48 \\
\text { JP }\end{array}$ \\
\hline
\end{tabular}

\section{KO KURIKULER}

\begin{tabular}{|c|l|}
\hline No & \multicolumn{1}{c|}{ Kegiatan } \\
\hline 1. & Ibadah Amaliyah \\
\hline 2. & Hafalan surat-surat Juz 'Amma \\
\hline 3. & Hafalan Mata Pelajaran Muthola'ah \\
\hline 4. & Hafalan Mata Pelajaran Bahasa Arab \\
\hline 5. & Hafalan Mata Pelajaran Nahwu \\
\hline 6. & Hafalan Mata Pelajaran Shorof \\
\hline 7. & Pembiasaan membaca Al-Qur'an sebelum pelajaran \\
\hline 8. & Pemberian tugas dengan media internet \\
\hline 9. & Darsul Masa' \\
\hline
\end{tabular}

\section{EKSTRAKURIKULER}




\begin{tabular}{|c|l|}
\hline No. & \multicolumn{1}{|c|}{ Kegiatan } \\
\hline 1. & Kepramukaan \\
\hline 2. & Jami'iyyatul Qura' \\
\hline 3. & Drum band \\
\hline 4. & Band \\
\hline 5. & Koor \\
\hline 6. & PMR \\
\hline 7. & Volly \\
\hline 8. & Habsyi \\
\hline 9. & Keputrian \\
\hline 10. & Futsal \\
\hline 11. & Theater \\
\hline 12. & Badminton \\
\hline 13. & Tari \\
\hline 14. & Kaligrafi \\
\hline 15. & Band \\
\hline 16. & Qasidah \\
\hline
\end{tabular}

\section{f. Kelebihan dan Kekurangan Kurikulum Modifikasi}

\section{1) Kelebihan Kurikulum Modifikasi}

a) Siswa lebih dapat maksimal dalam memahami pelajaran yang diberikan dengan alokasi waktu pembelajaran yang relatif maksimal (selama 4 tahun).

b) Siswa dapat memilih jurusan pendidikan yang dikehendakinya sesuai dengan kemampuan yang dimilikinya.

c) Siswa dapat mengikuti kegiatan organisasi kesiswaan sesuai dengan minat, bakat dan keterampilan yang dimilikinya.

d) Siswa berkesempatan bergabung dengan siswa kelas reguler lainnya ketika mereka memasuki kelas XI.

e) Strategi pembelajaran yang digunakan berpusat pada siswa dengan menggunakan strategi active learning, seperti group resume, reading a load, jigsaw learning, peer leason dan lain sebagainya.

f) Media pembelajaran yang digunakan adalah papan tulis, proyektor, laptop dan media yang disediakan oleh guru sendiri.

g) Sumber belajar siswa dapat diakses dengan buku-buku tambahan lainnya yang relevan dengan materi ajar yang diajarkan dan dapat pula diakses melalui media internet.

\section{2) Kekurangan Kurikulum Modifikasi}

a) Waktu pembelajaran selama 4 tahun.

b) Meningkatnya biaya pendidikan karena waktu pembelajaran ditempuh selama 4 tahun. 
Kurikulum modifikasi dari kurikulum pra full day dan kurikulum pasca full day ini merupakan kurikulum yang diterapkan oleh pihak lembaga Madrasah Aliyah AlIslam Joresan pada tahun ajaran 2013-2014. Madrasah Aliyah Al-Islam akan menggunakan waktu tempuh pembelajaran yang sama seperti kurikulum pra full day yaitu pembelajaran selama 4 tahun bagi siswa lulusan SMP/MTs di luar Al-Islam. Akan tetapi karena setiap kurikulum yang dilaksanakan di Madrasah Aliyah Al-Islam ini masing-masing memiliki kelebihan dan kekurangan, maka kurikulum modifikasi ini akan menjadi alternatif sebagai inovasi kurikulum yang nantinya diharapkan dapat membawa suatu program yang dapat dilaksanakan secara maksimal sehingga bukan hanya dapat mencapai tujuan pembelajaran dan tujuan pendidikan sesuai dengan visi dan misi Madarsah Aliyah Al-Islam Joresan akan tetapi juga dapat meningkatkan hasil belajar siswa dalam semua mata pelajaran yang ada dan dapat mengembangkan bakat, minat dan keterampilan yang dimiliki oleh siswa.

Penerapan kurikulum modifikasi ini dilaksanakan setelah adanya evaluasi kurikulum dari kurikulum sebelumnya yaitu kurikulum Full day School yang sudah berjalan selama 3 tahun dan berdampak kurang positif terhadap hasil belajar siswa dalam beberapa mata pelajaran tertentu dalam bidang agama Islam dan adanya pembatasan pengembangan diri siswa dalam bidang minat dan bakat yang siswa miliki.

Evaluasi kurikulum di Madrasah Aliyah Al-Islam Joresan ini dilaksanakan dengan melalui evaluasi kurikulum model CIPP yang meliputi :

a. Evaluasi konteks, yakni untuk mengetahui kelebihan dan kelemahan dari masingmasing kurikulum yang telah dilaksanakan di Madarsah Aliyah Al-Islam Joresan yakni mulai dari kurikulum pra full day dan kurikulum pasca full day school. Dengan mengetahui kelebihan dan kekurangan dari masing-masing kurikulum yang telah dilaksanakan ini akan mampu memberikan arah perbaikan yang diperlukan untuk kedepannya.

b. Evaluasi Masukan, evaluasi masukan ini sangat penting dalam memberikan pertimbangan terhadap keberhasilan pelaksanaan kurikulum serta memberikan program yang mampu membawa perubahan dan pembaharuan yang mampu menguntungkan pihak penerima inovasi yaitu siswa.

c. Evaluasi proses, evaluasi proses ini mengenai bagaimana pelaksanaan dari inovasi yang telah dilaksanakan, yakni evaluasi mulai dari pelaksanaan kurikulum pra dan pasca full day school yang sudah dilaksanakan di Madrasah Aliyah Al-Islam Joresan. 
d. Evaluasi Hasil, evaluasi hasil ini adalah untuk menentukan sampai sejauh mana kurikulum yang diimplementasikan tersebut telah dapat memenuhi kebutuhan siswa.

Setelah melalui beberapa proses evaluasi kurikulum yang telah dilaksanakan, maka hingga akhirnya pada tahun ajaran 2013/2014 Madrasah Aliyah Al-Islam Joresan menerapkan kurikulum modifikasi untuk siswa lulusan SMP/MTs lulusan diluar AlIslam Joresan dengan tahun waktu tempuh pembelajaran selama 4 tahun. Dan penerapan kurikulum modifikasi ini masih berjalan pada tahun 2019 sekarang ini.

Penerapan kurikulum modifikasi ini dilaksanakan dengan tujuan untuk Mewujudkan lulusan yang berwawasan luas dan berprestasi baik dalam bidang umum maupun agama dan mengembangkan minat dan bakat yang dimiliki sisiwa dalam menyongsong era globalisasi dan era Tekhnologi berlandaskan Iman dan Taqwa. Walaupun waktu tempuh pembelajaran dilaksanakan selama 4 tahun dan dapat meningkatkan biaya pendidikan tambahan selama 1 tahun, akan tetapi itu semua merupakan suatu program yang nantinya akan membawa siswa merasakan kenyamanan dalam pembelajaran tanpa adanya pembatasan minat dan bakat yang dimiliki oleh siswa

Selain itu kurikulum modifikasi ini juga diharapkan dapat memaksimalkan program intrakurikuler, ko kurikuler serta ekstrakurikuler yang ada di Madarsah Aliyah Al-Islam Joresan sesuai tujuan yang telah dirumuskan oleh pihak Madrasah.

\section{Inovasi Pendidikan}

Menurut kamus ilmiah, inovasi itu berarti pembaharuan (bidang pengembangan kemasyarakatan, sains/iptek. ${ }^{11}$ Ini karena dunia kita skekarang adalah dunia yang ditandai dengan perubahan tekhnologi dan begitu banyaknya sumber informasi, kebiasaan dan kemelekan informasi ini menjadi basis mereka untuk belajar terus-menerus (life long learning). ${ }^{12}$ Kata "innovation" (bahasa Inggris) sering diterjemahkan segala hal yang baru atau pembaharuan, tetapi ada yang menjadikan kata innovation menjadi kata indonesia yaitu “inovasi”. Inovasi kadang-kadang juga dipakai untuk menyatakan penemuan, karena hal yang baru itu hasil penemuan. Kata penemuan juga sering digunakan untuk menterjemahkan kata dari bahasa Inggris “discovery” dan "invention". ${ }^{13}$

Inovasi (innovation) ialah suatu ide, barang, kejadian, metode yang dirasakan dan diamati sebagai suatu hal yang baru bagi seseorang atau sekelompok orang (masyarakat),

${ }^{11}$ Pius A.Partanto, Dahlan Al-barry, Kamus Ilmiah Populer, (Surabaya : Arkola, 1994), hlm. 259.

12 Taufiq Amir, Inovasi Pendidikan Melalui Problem Based Learning : Bagaimana Pendidik Memberdayakan Pemelajar di Era Pengetahuan, (Jakarta : Kencana Prenada Media Group, 2009), hlm. 86-87.

${ }^{13}$ Udin Syaefudin Sa'ud, Inovasi Pendidikan, (Bandung : Alfabeta, 2010), hlm. 2. 
baik itu berupa hasil invention maupun discovery, dan inovasi diadakan untuk mencapai tujuan tertentu atau untuk memecahkan suatu masalah tertentu. ${ }^{14}$ Sedangkan yang dimaksud dengan inovasi pendidikan adalah suatu perubahan yang baru dan kualitatif berbeda dari hal (yang ada) sebelumnya dan sengaja diusahakan untuk meningkatkan kemampuan guna mencapai tujuan tertentu dalam pendidikan. ${ }^{15}$

a. Strategi Inovasi Pendidikan

Strategi inovasi pendidikan ini ada empat macam yaitu : a) strategi fasilitatif, b) strategi pendidikan, c) strategi bujukan, d) strategi paksaan.

1) Strategi Fasilitatif (facilitative Strategies). Pelaksanaan program perubahan sosial dengan menggunakan strategi fasilitatif artinya untuk mencapai tujuan perubahan sosial yang telah ditentukan, diutamakan penyediaan fasilitas dengan maksud agar program perubahan sosial akan berjalan dengan mudah dan lancar. ${ }^{16}$

2) Strategi Pendidikan (Re-Educative Strategies)

Dengan menggunakan strategi pendidikan berarti untuk mengadakan perubahan sosial dengan cara menyampaikan fakta dengan maksud orang akan menggunakan fakta atau informasi itu untuk menentukan tindakan yang akan dilakukan. Strategi pendidikan akan dapat digunakan secara tepat dalam kondisi dan situasi sebagai berikut :

a) Apabila perubahan sosial yang diinginkan, tidak harus terjadi dalam waktu yang singkat.

b) Apabila sasaran pendidikan (klien) belum memiliki keterampilan atau pengetahuan tertentu yang diperlukan untuk melaksanakan program perubahan sosial.

c) Apabila menurut perkiraan akan terjadi penolakan yang kuat oleh klien terhadap perubahan yang diharapkan.

d) Apabila dikehendaki perubahan yang sifatnya mendasar dari pola tingkah laku yang sudah ada ke tingkah laku yang baru.

e) Apabila alasan atau latar belakang perlunya perubahan telah diketahui dan dimengerti atas dasar sudut pandang klien sendiri, serta diperlukan adanya kontrol dari klien.

3) Strategi Bujukan (Persuasive Strategies)

\footnotetext{
${ }^{14}$ Ibid., hlm. 3

${ }^{15}$ Suryosubroto, Beberapa Aspek Dasar-dasar Kependidikan, (Jakarta : Rineka Cipta, 2010), hlm. 116.

${ }^{16}$ Ibid., hlm. 63.
} 
Program perubahan sosial dengan menggunakan strategi bujukan, artinya untuk mencapai tujuan perubahan sosial dengan cara membujuk (merayu) agar sasaran perubahan (klien), mau mengikuti perubahan sosial yang direncanakan. Untuk berhasilnya penggunaan strategi bujukan perlu mempertimbangkan dan tepat digunakan bila klien (sasaran perubahan):

a) Tidak berpartisipasi dalam proses perubahan sosial.

b) Berada pada tahap evaluasi atau legitimasi dalam proses pengambilan keputusan untuk menerima atau menolak perubahan sosial.

c) Diajak untuk mengalokasikan sumber penunjang perubahan dari suatu kegiatan atau program ke kegiatan atau program yang lain.

4) Strategi Paksaan (Power Strategies)

Pelaksanaan program perubahan sosial dengan menggunakan strategi paksaan, artinya dengan cara memaksa klien (sasaran perubahan) untuk mencapai tujuan perubahan. ${ }^{17}$ Penggunaan strategi paksaan perlu mempertimbangkan hal-hal sebagai berikut :

a) Strategi paksaan dapat digunkan apabila partisipasi klien terhadap proses perubahan sosial rendah dan tidak mau meningkatkan partisipasinya.

b) Strategi paksaan juga tepat digunakan apabila klien tidak merasa perlu untuk berubah atau tidak menyadari perlunya perubahan sosial.

c) Strategi paksaan tidak efektif jika klien tidak memiliki sararan penunjang untuk mengusahakan perubahan dan pelaksana perubahan juga tidak mampu mengadakannya .

d) Strategi paksaan tepat digunakan jika perubahan sosial yang diharapkan harus terwujud dalam waktu yang singkat.

e) Strategi paksaan juga tepat dipakai untuk menghadapi usaha penolakan terhadap perubahan sosial.

f) Strategi paksaan dapat digunakan jika klien sukar untuk mau menerima perubahan sosial artinya sukar dipengaruhi.

g) Strategi paksaan dapat juga digunakan untuk menjadin keamanan percobaan sosial yang telah direncanakan. ${ }^{18}$

b. Contoh Inovasi Pendidikan

\footnotetext{
${ }^{17}$ Ibid., hlm. 68.

${ }^{18}$ Ibid., hlm. 68-69.
} 
Berikut ini adalah contoh-contoh inovasi pendidikan dalam setiap komponen pendidikan atau komponen sistem sosial sesuai dengan yang dikemukakan oleh B. Miles, dengan perubahan isi disesuaikan dengan perkembangan pendidikan dewasa ini : 19

1) Pembinaan personalia. Pendidikan yang merupakan bagian dari sistem tentu menentukan personil (orang) sebagai komponen sistem. Inovasi yang sesuai dengan komponen personil misalnya : peningkatan mutu guru, sistem kenaikan pangkat, aturan tata tertib siswa dan sebagainya.

2) Banyaknya personil dan wilayah kerja. Sistem sosial tentu menjelaskan tentang berapa jumlah personalia yang terikat dalam sistem serta dimana wilayah kerjanya. Inovasi pendidikan yang relevan dengan aspek ini misalnya : berapa ratio guru dan siswa pada satu sekolah dalam sistem PAMONG pernah diperkenalkan ini dengan ratio $1: 200$ artinya satu guru dengan 200 siswa.

3) Fasilitas fisik. Sistem sosial termasuk juga sistem pendidikan mendayagunakan berbagai sarana dan hasil tekhnologi untuk mencapai tujuan. Inovasi pendidikan yang sesuai dengan komponen ini misalnya : perubahan bentuk tempat duduk, perubahan pengaturan dinding ruangan, perlengkapan perabot laboratorium bahasa, penggunaan CCTV dan lain sebagainya.

4) Penggunaan waktu. Suatu sistem pendidikan tentu memiliki perencanaan penggunaan waktu. Inovasi yang relevan dengan komponen ini misalnya : penggunaan waktu belajar (semester, catur wulan, pembuatan jadwal pelajaran yang dapat memberi kesempatan kepada mahasiswa untuk memilih waktu sesuai keperluan, dan sebagainya.

5) Perumusan tujuan. Sistem pendidikan tentu memiliki rumusan tujuan yang jelas. Inovasi yang relevan dengan komponen ini, misalnya : perubahan tujuan tiap jenis sekolah yang disesuaikan dengan perkembangan tantangan kehidupan, perubahan rumusan tujuan pendidikan nasional dan sebagainya.

6) Prosedur. Sistem pendidikan tentu mempunyai prosedur untuk mencapai tujuan. Inovasi pendidikan yang relevan dengan komponen ini misalnya : penggunaan kurikulum baru, cara membuat persiapan mengajar, pengajaran individual, pengajaran kelompok, dan sebagainya.

7) Peran yang diperlukan. Dalam sistem sosial temasuk sistem pendidikan diperlukan kejelasan peran yang diperlukan untuk melancarkan jalannya pencapaian tujuan

\footnotetext{
${ }^{19}$ Ibid., hlm. 8-11.
} 
inovasi yang relevan dengan komponen ini, misalnya: peran guru sebagai pemakai media, pera guru sebagai pengelola kegiatan kelompok, guru sebagai anggota team teaching dan sebagainya.

8) Wawasan dan perasaan. Dalam interaksi sosial biasanya berkembang suatu wawasan dan perasaan tertentu yang akan menunjang kelancaran pelaksanaan tugas. Inovasi yang relevan dengan komponen ini misalnya : wawasan pendidikan seumur hidup, wawasan pendekatan keterampilan proses, dan sebagainya.

9) Bentuk hubungan antar bagian (mekanisme kerja). Dalam sistem pendidikan perlu ada kejelasan hubungan antara bagian atau mekanisme kerja antara bagian dalam pelaksanaan kegiatan untuk mencapai tujuan. Inovasi yang relevan dengan komponen ini misalnya : diadakan perubahan pembagian tugas antar seksi, di perguruan tinggi diadakan perubahan hubungan kerja antara jurusan, fakultas, dan biro tentang pengadministrasian nilai mahasiswa dan lain sebagainya.

10) Hubungan dengan sistem yang lain. Dalam pelaksanaan kegiatan pendidikan dalam beberapa hal harus berhubungan atau bekerja sama dengan sistem yang lain. Inovasi yang relevan dengan bidang ini misalnya : dalam pelaksanaan usaha kesehatan sekolah bekerjasama atau berhubungan dengan Departemen Kesehatan, data pelaksanaan KKN harus bekerjasama dengan Pemerintah Daerah setempat dan sebagainya.

11) Strategi. Yang dimaksud dengan strategi dalam hal ini ialah tahap-tahap kegiatan yang dilaksanakan untuk mencapai tujuan inovasi pendidikan. Adapun macam dan pola strategi yang digunakan sangat sukar untuk diklasifikasikan, tetapi secara kronologis biasanya menggunakan urutan sebagai berikut : 1) desain, 2) kesadaran dan perhatian, 3) evaluasi, 4) percobaan. ${ }^{20}$

\section{Inovasi dan Pengembangan Kurikulum}

a. Pengertian Inovasi Kurikulum

Kurikulum dapat dipandang sebagai suatu rancangan pendidikan. Sebagai suatu rancangan, kurikulum menentukan pelaksanaan hasil pendidikan. ${ }^{21}$ Inovasi kurikulum dan

${ }^{20}$ Ibid., hlm. 11.

${ }^{21}$ Nana Syaodih Sukmadinata, Pengembangan Kurikulum : Teori dan Praktek, (Bandung : Remaja Rosdakarya, 2009), hlm. 58. Lihat juga Dimyati dan Mudjiono, Belajar dan Pembelajaran, (Jakarta : Rineka Cipta, 2009), hlm .266. 
pembelajaran dapat diartikan sebagai suatu ide, gagasan atau tindakan-tindakan tertentu dalam bidang kurikulum dan pembelajaran yang dianggap baru untuk memecahkan masalah pendidikan. $^{22}$

b. Bentuk-bentuk Inovasi Kurikulum ${ }^{23}$

1) Inovasi Kurikulum Berbasis Kompetensi

Kurikulum berbasis kompetensi merupakan seperangkat rencana dan pengaturan tentang kompetensi dan hasil belajar yang harus dicapai siswa, penilaian, kegiatan belajar mengajar dan pemberdayaan sumber daya pendidikan dan mengembangkan sekolah. Jika dilihat dari prinsip-prinsip dasar kurikulum berbasis kompetensi ini adalah sebagai berikut :

a) Menekankan pada hasil (outcomes)

b) Outcomes merupakan kompetensi yang dapat diukur

c) Evaluasi keberhasilan merupakan pengukuran penguasaan kompetensi yang telah dicapai

d) Menekankan pada kemampuan berfikir lebih tinggi.

Disamping itu, kurikulum berbasis kompetensi ditandai dengan ciri-ciri, antara lain :

a) Lebih menitikberatkan pencapaian target kompetensi dari pada penguasaan materi.

b) Lebih mengakomodasikan keragaman kebutuhan dan sumber daya pendidikan yang tersedia.

c) Memberikan kebebasan yang lebih luas kepada pelaksana pendidikan di lapangan untuk mengembangkan dan melaksanakan program pembelajaran sesuai dengan kebutuhan. ${ }^{24}$

2) Inovasi Kurikulum Berbasis Masyarakat

Kurikulum berbasis masyarakat adalah kurikulum yang bahan dan objek kajiannya, kebijakan dan ketetapan yang dilakukan di daerah, disesuaikan dengan kondisi lingkungan alam, sosial, ekonomi, budaya dan disesuaikan dengan kebutuhan pembangunan daerah yang perlu dipelajari oleh siswa di daerah tersebut. ${ }^{25}$

\footnotetext{
${ }^{22}$ Asrori Ardiansyah, Konsep Inovasi Kurikulum, (Online), (http://www.majalahpendidikan.com/2011/04/konsep-inovasi-kurikulum.html), diakses 13 Januari 2018

${ }^{23}$ Ayi Suherman, Inovasi Kurikulum, (Online), (http://file.upi.edu/Direktori/DUALMODES/INOVASI_PENDIDIKAN/Modul_4-Inovasi_Kurikulum.pdf). diakses 20 Maret 2018

${ }^{24}$ Muhaimin, Agus Maimun, Kurikulum Berbasis Kompetensi di Perguruan Tinggi Agama Islam (Yogyakarta : Pustaka Pelajar, 2005), hlm. 44.

${ }^{25}$ Ibid., hlm. 103.
} 
Sebagai implikasinya, pendidikan menjadi usaha kolaboratif yang melibatkan partisipasi masyarakat didalamnya. Partisipasi dalam konteks ini berupa kerjasama antara warga dengan pemerintah dalam merencanakan, menjaga dan mengembangkan aktivitas pendidikan. Sebagai sebuah kerjasama, maka masyarakat diasumsikan mempunyai aspirasi yang harus diakomodasikan dalam proses perencanaan dan pelaksanaan suatu program pendidikan. ${ }^{26}$ Karakteristik pembelajaran pada kurikulum berbasis masyarakat ini adalah sebagai berikut :

a) Pembelajaran berorientasi pada masyarakat.

b) Disiplin kelas berdasarkan tanggung jawab bersama bukan berdasarkan paksaan atau kebebasan.

c) Metode mengajar terutama dititikberatkan pada pemecahan masalah untuk memenuhi kebutuhan perorangan dan kebutuhan sosial dan kelompok.

d) Bentuk hubungan atau kerjasama sekolah dan masyarakat adalah mempelajari sumber-sumber masayarakat dan memperbaiki masyarakat tersebut. ${ }^{27}$

3) Inovasi Kurikulum Berbasis Keterpaduan

Integrated curriculum meniadakan batas-batas berbagai mata pelajaran dan menyajikan bahan pelajaran dalam bentuk unit dan keseluruhan. Dengan kebulatan bahan pelajaran diharapkan mampu membentuk kepribadian murid yang integral. ${ }^{28}$ Kurikulum terpadu ini juga mudah untuk disesuaikan dengan minat, kesanggupan, kematangan murid dan dapat meningkatkan aktivitas anak karena dirangsang untuk berfikir sendiri dan bekerja sendiri atau bekerja dengan kelompok. ${ }^{29}$ Ciri-ciri bentuk organisasi kurikulum adalah :

a) Berdasarkan filsafat pendidikan pancasila

b) Berdasarkan psikologi belajar Gestalt dan field theory

c) Berdasarkan landasan sosiologis dan sosio-kultural

d) Berdasarkan kebutuhan, minat dan tingkat perkembangan kepertumbuhan peserta didik

e) Ditunjang oleh semua mata pelajaran atau bidang study yang ada

\footnotetext{
${ }^{26}$ Zubaedi, Pendidikan Berbasis Masyarakat : Upaya Menawarkan Terhadap Berbagai Problem Sosial, (Yogyakarta : Pustaka Pelajar, 2006), hlm. 130-131.

27 Sudarwan Danim, Inovasi Pendidikan : dalam Upaya Peningkatan Profesionalisme Tenaga Kependidikan, (Bandung : Pustaka Setia, 2002), hlm. 60.

${ }^{28}$ Suryosubroto, Tatalaksana Kurikulum, (Jakarta : Rineka Cipta, 2005), hlm. 4.

${ }^{29}$ Suryosubroto, Manajemen Pendidikan Sekolah, (Jakarta : Rineka Cipta, 2004), hlm. 37.
} 
f) Sistem penyampaiannya dengan menggunakan sistem pengajaran unit, yakni unit pengalaman dan unit mata pelajaran

g) Peran guru sama aktifnya dengan peran peserta didik. ${ }^{30}$

4) Berbagai Jenis Inovasi dalam Kurikulum dan Pembelajaran

a) Pemberlakuan Kurikulum Tingkat Satuan pendidikan (KTSP)

b) Penyelenggaraan Sekolah Lanjutan Tingkat Pertama Terbuka (SLTPT)

c) Pengajaran melalui modul

d) Pembelajaran melalui komputer

e) Materi kewirausahan. ${ }^{31}$

\section{PENUTUP}

Inovasi kurikulum yang dilksanakan di Madrasah Aliyah Al-Islam Joresan ini dilaksanakan dalam tiga tahap yakni :Inovasi kurikulum pra full day/program kelas intensif yang dilaksanakan pada tahun 1984, dengan waktu tempuh pembelajaran selama 4 tahun. Inovasi kurikulum full day school yang dilaksanakan pada tahun 2010, dengan waktu tempuh pembelajaran selama 3 tahun. Inovasi kurikulum modifikasi yang dilaksanakan pada tahun 2013 sampai sekarang dengan waktu tempuh pembelajaran selama 4 tahun dengan hasil modifikasi antara kurikulum pra full day dan kurikulum full day school. Dampak inovasi kurikulum full day meliputi : Terhadap hasil belajar siswa : rendahnya nilai siswa pada mata pelajaran agama seperti bahasa Arab, Nahwu, Shorof, Tafsir Al-Qur'an dan Hadits yang mayoritas belum tuntas KKM nya.Terhadap pengembangan diri siswa dengan dibatasinya siswa untuk: Tidak boleh memilih jurusan pendidikan yang diinginkannya. Tidak boleh mengikuti kegiatan organisasi kesiswaan seperti Koordinator kepramukaan dan OPMI (Organisasi Pelajar Madrasah Al-Islam). Setelah mengetahui adanya dampak yang kurang memuaskan dari pelaksanaan inovasi kurikulum di Madrasah Aliyah Al-Islam Joresan, maka pihak Madrasah pun juga mengambil tindakan secepatnya dengan mengadakan inovasi lagi pada tahun ajaran 2013-2014 yakni dengan menerapkannya kurikulum modifikasi antara kurikulum pra dan pasca full day school, dan kurikulum modifikasi tersebut dilaksanakan sampai sekarang pada tahun 2019.

\footnotetext{
${ }^{30}$ Udin Syaefudin Sa’ud, Invasi Pendidikan., hlm. 116.

31 Anin Nurhayati, Inovasi Kurikulum : Telaah Terhadap Pengembangan Kurikulum Pendidikan Pesantren, (Yogyakarta : Teras, 2010), hlm. 93.
} 


\section{DAFTAR PUSTAKA}

Amir, Taufik. Inovasi Pendidikan Melalui Problem Based Learning : Bagaimana Pendidik Memberdayakan Pemelajar di Era Pengetahuan, Jakarta : Kencana Prenada Media Group, 2009.

Ardiansyah, Asrori, Konsep Inovasi Kurikulum, (Online), (http://www.majalahpendidikan.com/2011/04/konsep-inovasi-kurikulum.html), diakses 13 Januari 2012

Danim, Sudarwan, Inovasi Pendidikan : dalam Upaya Peningkatan Profesionalisme Tenaga Kependidikan, Bandung: Pustaka Setia, 2002.

Dimyati dan Mudjiono, Belajar dan Pembelajaran, Jakarta : Rineka Cipta, 2009.

Hamalik, Oemar. Manajemen Pengembangan Kurikulum, Bandung : PT Remaja Rosdakarya, 2008.

Irwanto, Focus Group Discussion. Jakarta : Pusat Kajian Pembangunan Masyarakat Universitas Katolik Indonesia Atma Jaya, 1998.

Margono, Metodologi Penelitian Pendidikan, Jakarta : Rineka Cipta, 2009.

Miles, Matthew B. Huberman, Michael A. Analisa Data Kualitatif. Jakarta : UI- Press,

Moleong, Lexy J. Metodologi Penelitian Kualitatif. Bandung : Remaja Rosdakarya, 1998.

Muhaimin, Maimun, Agus, Kurikulum Berbasis Kompetensi di Perguruan Tinggi Agama Islam, Yogyakarta : Pustaka Pelajar, 2005.

Nurhayati, Anin, Inovasi Kurikulum: Telaah Terhadap Pengembangan Kurikulum Pendidikan Pesantren, Yogyakarta : Teras, 2010.

Partanto, Pius A. Al-Barry, M. Dahlan, Kamus Ilmiah Populer. Surabaya : Arkola, 1994.

Ramayulis, Ilmu Pendidikan Islam, Jakarta : Kalam Mulia, 2006.

Sa’ud, Udin Syaefudin, Inovasi Pendidikan, Bandung : Alfabeta, 2010.

Suherman, Ayi, Inovasi Kurikulum, (Online), (http://file.upi.edu/Direktori/DUALMODES/INOVASI_PENDIDIKAN/Modul_4-Inovasi_Kurikulum.pdf). diakses 20 Maret 2012

Sugiyono, Memahami Penelitian Kualitatif . Bandung : Alfabeta, 2005.

Sugiyono, Metode Penelitian Pendidikan : Pendekatan Kuantitatif, Kualitatif dan RD, Bandung: Alfabeta, 2005.

Sukmadinata, Nana Syaodih, Pengembangan Kurikulum : Teori dan Praktek, Bandung : Remaja Rosdakarya, 2009. 
Suryosubroto, Beberapa Aspek Dasar-dasar Kependidikan, Jakarta : Rineka Cipta, 2010.

Suryosubroto, Tatalaksana Kurikulum, Jakarta : Rineka Cipta, 2005.Suryosubroto, Manajemen Pendidikan Sekolah, Jakarta : Rineka Cipta, 2004.

Zubaedi, Pendidikan Berbasis Masyarakat : Upaya Menawarkan Terhadap Berbagai Problem Sosial, Yogyakarta : Pustaka Pelajar, 2006. 